\title{
Application of Solanum lycopersicum Glucose-6- phosphate Dehydrogenase to NADPH-generating System for Cytochrome P450 Reactions
}

\author{
Chan Mi Park, Heon Jeong, Sang Hoon Ma, Hyun Min Kim, Young Hee Joung, and Chul-Ho Yun* \\ School of Biological Sciences and Technology, Chonnam National University, Gwangju 61186, Republic of Korea
}

Received: May 20, 2019 / Accepted: July 10, 2019

\begin{abstract}
Cytochrome P450 (P450 or CYP) is involved in the metabolism of endogenous and exogenous compounds in most organisms. $\mathrm{P} 450 \mathrm{~s}$ have great potential as biocatalysts in the pharmaceutical and fine chemical industries because they catalyze diverse oxidative reactions using a wide range of substrates. The high-cost nicotinamide cofactor, NADPH, is essential for $\mathbf{P 4 5 0}$ reactions. Glucose-6-phosphate dehydrogenase (G6PDH) has been commonly used in NADPH-generating systems (NGSs) to provide NADPH for P450 reactions. Currently, only two G6PDHs from Leuconostoc mesenteroides and Saccharomyces cerevisiae can be obtained commercially. To supply high-cost G6PDH cost-effectively, we cloned the cytosolic G6PDH gene of Solanum lycopersicum (tomato) with 6xHis tag, expressed it in Escherichia coli, and purified the recombinant G6PDH (His-G6PDH) using affinity chromatography. In addition, enzymatic properties of His-G6PDH were investigated, and the His-G6PDH-coupled NGS was optimized for P450 reactions. His-G6PDH supported CYP102A1-catalyzed hydroxylation of omeprazole and testosterone by NADPH generation. This result suggests that tomato His-G6PDH could be a cost-effective enzyme source for NGSs for P450-catalyzed reactions as well as other NADPH-requiring reactions.
\end{abstract}

Keywords: Cytochrome P450, tomato glucose-6-phosphate dehydrogenase, heterologous expression, NADPH-generating system

\section{Introduction}

Cytochrome P450 (P450 or CYP) belongs to the monooxygenase family involved in the metabolism of various endogenous and exogenous compounds. P450s catalyze diverse oxidative reactions using a wide range of substrates [1,2]. In humans, P450s are responsible for about $75 \%$ of all drug metabolism. CYP3A4 is involved in about $50 \%$ of drug metabolism [3, 4]. It is generally accepted that $\mathrm{P} 450 \mathrm{~s}$ have great potential as biocatalysts in drug development.

\section{*Corresponding author}

Tel: +82-62-530-2194, Fax: +82-62-530-2199

E-mail: chyun@jnu.ac.kr

๑ 2019, The Korean Society for Microbiology and Biotechnology
CYP102A1 from Bacillus megaterium consists of catalytic heme domain and NADPH-dependent reductase domain in a single peptide [5]. CYP102A1 is more appreciated as a biocatalyst because of its higher activity and solubility. Engineering of CYP102A1 through site-directed and random mutagenesis has been reported to generate human P450-like activities towards various marketed drugs and steroids. CYP102A1 R47L/F87V/L188Q mutant is known to have high activity toward non-natural substrates [6-8]. However, some challenges exist for applying $\mathrm{P} 450 \mathrm{~s}$ to drug development, because they require high-cost nicotinamide cofactor (NADPH) supply for P450 reactions. Therefore, enzyme-coupled cofactor regenerating system is generally used to provide NADPH for P450 reaction [9, 10].

Glucose-6-phosphate dehydrogenase (G6PDH, EC 
1.1.1.49) catalyzes oxidation of glucose-6-phosphate (G6P) to 6-phospho- $\delta$-gluconolacton simultaneously with reduction of nicotinamide adenine dinucleotide phosphate $\left(\mathrm{NADP}^{+}\right)$to $\mathrm{NADPH}$. G6PDH is a key enzyme of the rate-limiting step of oxidative pentose phosphate pathway (OPPP). The major function of OPPP is to provide $\mathrm{NADPH}$ for reductive biosynthesis and to supply pentose for nucleotide synthesis [11]. G6PDH is commonly used in NADPH-generating system (NGS) of P450-catalyzed reactions. However, only two G6PDHs from bacteria Leuconostoc mesenteroides (LMG) and yeast Saccharomyces cerevisiae (SCG) can be obtained commercially, while no plant G6PDHs are available at present.

In plants, G6PDH is generally classified to three isoforms depending on cellular localization, which are cytosolic (Cy-G6PDH), plastidic (P-G6PDH), and peroxisomal G6PDH [12-15]. G6PDHs were purified from barley (Hordeum vulgare) roots and potato (Solanum tuberosum) tuber and their kinetic parameters were determined [16, 17]. Cy-G6PDH and P-G6PDH from barley were expressed in Escherichia coli and their enzymatic properties were studied [18, 19]. Cy-G6PDH and P-G6PDH from potato were expressed and purified as a GST-fusion protein in E. coli [13]. In addition, several pieces of evidence show that enzymatic activity and expression level of plant G6PDHs were increased by environmental stresses such as salt and drought in sugarcane [20], barley [21], soybean [22, 23], and tomato [24]. However, to our knowledge, there are no reports of enzymatic characterization of recombinant G6PDH from tomato (Solanum lycopersicum).

In this study, a cytosolic G6PDH gene of S. lycopersicum was cloned with $6 \mathrm{xHis}$-tag and heterologously expressed in $E$. coli. We investigated the enzymatic properties of recombinant G6PDH (His-G6PDH) after purification by affinity chromatography. We compared catalytic activity of His-G6PDH to two commercial G6PDHs, LMG and SCG. Finally, we showed that His-G6PDH could successfully support $\mathrm{P} 450$-catalyzed reactions by generating NADPH.

\section{Materials and Methods}

\section{Materials}

G6P, $\mathrm{NADP}^{+}$, nicotinamide adenine dinucleotide
$\left(\mathrm{NAD}^{+}\right)$, LMG, and SCG were obtained from SigmaAldrich (USA). Omeprazole and testosterone were purchased from Wako (Japan). All other chemicals were analytical grade.

\section{RNA isolation and CDNA synthesis}

Total RNA was isolated from tomato leaves $(S$. lycopersicum) using RNeasy Plant Mini Kit (QIAGEN, Germany), and cDNA was synthesized by reverse transcription using $1 \mu \mathrm{g}$ of the total RNA and QuantiTect Reverse Transcription Kit (QIAGEN) following the manufacturer's protocol.

\section{Amplification of S. lycopersicum G6PDH gene}

To amplify the $G 6 P D H$ gene in the genome of $S$. lycopersicum, PCR was carried out using above cDNA, specific primers (forward: 5'-GATGGCGGCATCATGGTGTATTG-3', reverse: 5'-ACTTATAGTGTGGGAGGGATCCAT-3'), and Platinum Taq DNA Polymerase High Fidelity (Invitrogen, USA) according to manufacturer's protocol. PCR was initiated at $94^{\circ} \mathrm{C}$ for $2 \mathrm{~min}$ and run through 35 cycles of $94^{\circ} \mathrm{C}$ for $30 \mathrm{~s}, 55^{\circ} \mathrm{C}$ for $30 \mathrm{~s}$, and $68^{\circ} \mathrm{C}$ for $90 \mathrm{~s}$. After completing cycles, the reaction mixture was held at $68^{\circ} \mathrm{C}$ for $5 \mathrm{~min}$ and cooled at $4{ }^{\circ} \mathrm{C}$ for $5 \mathrm{~min}$. The PCR product was inserted into the pGEM-T easy vector by T4 DNA ligase (Promega, USA), and this ligate was introduced into $E$. coli $\mathrm{DH} 5 \alpha$ cells via transformation. The G6PDH-pGEM-T easy plasmid was isolated from the transformed $\mathrm{DH} 5 \alpha$ cells using HiGene Plasmid Mini Prep Kit (BIOFACT, Korea), and the plasmid sequence was analyzed via DNA sequencing (Cosmogenetech, Korea).

\section{Cloning of S. lycopersicum G6PDH gene into expression vector}

To introduce restriction sites, PCR was performed using the G6PDH-pGEM-T easy plasmid as a template, specific primers (NdeI forward: 5'-CATATGGCGGCATCATGGTGTATTG-3' and XhoI reverse: 5'-CTCGAGTTATAGTGTGGGAGGGATC-3'), and Platinum Taq DNA Polymerase High Fidelity (Invitrogen), according to manufacturer's protocol. PCR condition followed the same procedure as shown above. After double-digestion of the PCR product and pET-28a expression vector (Merck KGaA, Germany) with NdeI-XhoI enzymes (NEB, USA), they were purified using LaboPass gel 
(Cosmogenetech). G6PDH gene insert was ligated into linearized pET-28a expression vector by T4 DNA ligase (TaKaRa, Japan). This ligate was introduced into DH5 $\alpha$ cells through transformation. The plasmid of G6PDHNX-pET-28 was prepared using Plasmid Mini Prep Kit (BIOFACT, Korea), and DNA sequence of the plasmid was verified by DNA sequencing (Cosmogenetech).

\section{Heterologous expression in E. coli and purification of His- G6PDH}

Transformed E. coli BL21(DE3) cells with the plasmid of G6PDH-NX-pET-28 were grown in Luria-Bertani (LB) broth containing kanamycin $(50 \mu \mathrm{g} / \mathrm{ml})$ at $37^{\circ} \mathrm{C}$ for overnight. Precultured cells were inoculated to $500 \mathrm{ml}$ of LB broth containing kanamycin $(50 \mu \mathrm{g} / \mathrm{ml})$ and were grown at $37^{\circ} \mathrm{C}$ with shaking until 0.4 of $\mathrm{OD}_{600}$. Protein expression was induced by adding $0.4 \mathrm{mM}$ isopropyl $\beta$-D1-thiogalactopyranoside (IPTG). The culture was grown at $30^{\circ} \mathrm{C}$ with shaking at $200 \mathrm{rpm}$ for $24 \mathrm{~h}$. The cells were harvested by centrifugation at $3000 \mathrm{rpm}$ for $20 \mathrm{~min}$. Cell pellet was resuspended with lysis buffer $(50 \mathrm{mM}$ sodium phosphate, $\mathrm{pH} 8.0,300 \mathrm{mM} \mathrm{NaCl}, 10 \mathrm{mM}$ imidazole, and $1 \mathrm{mM}$ phenylmethylsulfonyl fluoride (PMSF)) and lysed by sonication. After centrifuge at $14000 \mathrm{rpm}$ at $4^{\circ} \mathrm{C}$ for $30 \mathrm{~min}$, the supernatant was loaded to a Ni-NTA column (QIAGEN) equilibrated with binding buffer $(50 \mathrm{mM}$ sodium phosphate, $\mathrm{pH} 8.0,300 \mathrm{mM} \mathrm{NaCl}$, and $10 \mathrm{mM}$ imidazole). Non-tagged proteins were washed by washing buffer (50 mM sodium phosphate, $\mathrm{pH} 8.0,300 \mathrm{mM}$ $\mathrm{NaCl}$, and $20 \mathrm{mM}$ imidazole). His-tagged protein was eluted by adding elution buffer $(50 \mathrm{mM}$ sodium phosphate, $\mathrm{pH}$ 8.0, $300 \mathrm{mM} \mathrm{NaCl}$, and $250 \mathrm{mM}$ imidazole). Elution profile and purity of His-G6PDH protein were confirmed by SDS-PAGE and staining with Coomassie Brilliant Blue R-250. The concentration of His-G6PDH was quantitated by extinction coefficient after dialysis with $100 \mathrm{mM}$ potassium phosphate buffer $(\mathrm{pH}$ 7.4) containing 1 mM EDTA.

\section{Activity assay of G6PDHs}

Routine assays for measuring G6PDH activity were performed at $37^{\circ} \mathrm{C}$ in a VERSA max microplate reader (Molecular Devices, USA). The reaction was initiated by adding enzyme to $100 \mathrm{mM}$ potassium phosphate buffer (pH 7.4) containing $3.3 \mathrm{mM} \mathrm{G6P}$ and $0.22 \mathrm{mM} \mathrm{NADP}^{+}$.
Generation of NADPH was monitored at $340 \mathrm{~nm}$ for $5 \mathrm{~min}$ with $10 \mathrm{~s}$ intervals. The specific activity $(\mu \mathrm{mol}$ product $/ \mathrm{min} / \mu \mathrm{mol}$ enzyme) was calculated by the molar attenuation coefficient of NADPH $\left(6220 \mathrm{M}^{-1} \mathrm{~cm}^{-1}\right.$ at $340 \mathrm{~nm})$ and initial velocity $\left(v_{0}\right)$. To determine kinetic parameters $\left(K_{\mathrm{m}}\right.$ and $\left.V_{\max }\right)$ for $\mathrm{G} 6 \mathrm{P}$ and $\mathrm{NADP}^{+}$, specific activity of three G6PDHs was measured in $100 \mathrm{mM}$ potassium phosphate buffer ( $\mathrm{pH} 7.4$ ) containing $0.22 \mathrm{mM}$ $\mathrm{NADP}^{+}$and range of 0 to $10 \mathrm{mM} \mathrm{G6P}$ or containing $3.3 \mathrm{mM}$ G6P and range of 0 to $2 \mathrm{mM} \mathrm{NADP}{ }^{+}$, respectively. Kinetic parameters were determined using nonlinear regression with Michaelis-Menten equation of GraphPad PRISM 5 (GraphPad Software, USA). To investigate optimal temperature of His-G6PDH, assays were performed at $26,30,35,37,40,42$, and $45^{\circ} \mathrm{C}$. Effect of $\mathrm{pH}$ on His-G6PDH activity was analyzed at $\mathrm{pH}$ of 4, 5, $6,7,7.4,8$, and 9 . Effect of buffer concentration was analyzed in $0,1,5,10,20,50,100,200$, and $500 \mathrm{mM}$ potassium phosphate buffer (pH 7.4).

\section{Expression and purification of CYP102A1 enzyme}

A triple mutant (R47L/F87V/L188Q) of CYP102A1 was heterologously expressed in the E. coli $\mathrm{DH} 5 \alpha \mathrm{F}^{\circ}$-IQ and purified as previously described [25]. Transformed cells with the plasmid of CYP102A1 mutant-pCW were grown in $5 \mathrm{ml}$ of LB broth containing ampicillin $(100 \mu \mathrm{g} /$ $\mathrm{ml})$ at $37^{\circ} \mathrm{C}$ for overnight. Precultured cells were inoculated to $250 \mathrm{ml}$ of terrific broth (TB) containing ampicillin $(100 \mu \mathrm{g} / \mathrm{ml})$ and were grown at $37^{\circ} \mathrm{C}$ with shaking at $200 \mathrm{rpm}$ until 0.8 of $\mathrm{OD}_{600}$. Expression of CYP102A1 mutant was induced by adding $0.5 \mathrm{mM}$ IPTG and $\delta$ aminolevulinic acid $(1 \mathrm{mM})$. The culture was grown at $30^{\circ} \mathrm{C}$ with shaking at $190 \mathrm{rpm}$ for $24 \mathrm{~h}$. The cells were harvested by centrifugation at $5000 \mathrm{~g}$ for $15 \mathrm{~min}$. The cell pellet was resuspended in TES buffer $(100 \mathrm{mM}$ Tris-acetate, $\mathrm{pH}$ 7.6, $500 \mathrm{mM}$ sucrose, $0.5 \mathrm{mM}$ EDTA, and $0.2 \mathrm{mg} / \mathrm{ml}$ lysozyme). After centrifuge at $5000 \mathrm{~g}$ for $20 \mathrm{~min}$, pellet was resuspended in sonication buffer (100 mM potassium phosphate, $\mathrm{pH} 7.4,20 \%$ glycerol, $1 \mathrm{mM}$ EDTA, $0.1 \mathrm{mM}$ dithiothreitol, and $1 \mathrm{mM}$ PMSF) and lysed by sonication. The lysate was centrifuged at $100000 \mathrm{~g}$ at $4^{\circ} \mathrm{C}$ for $90 \mathrm{~min}$ and then soluble cytosolic fraction was collected. The concentration of CYP102A1 mutant was determined from the CO-difference spectra using $\varepsilon=91 \mathrm{mM}^{-1} \mathrm{~cm}^{-1}[26]$. 


\section{Activity assay of CYP102A1 mutant toward omeprazole and testosterone}

The CYP102A1 mutant $(0.2 \mu \mathrm{M})$ was incubated with NGS in $100 \mathrm{mM}$ potassium phosphate buffer ( $\mathrm{pH}$ 7.4) at $37^{\circ} \mathrm{C}$ for $5 \mathrm{~min}$. NGS consisted of $3.3 \mathrm{mM} \mathrm{G} 6 \mathrm{P}$ and $0.22 \mathrm{mM} \mathrm{NADP}^{+}$with $2 \mathrm{nM}$ His-G6PD, $0.5 \mathrm{nM} \mathrm{LMG}$, or $0.5 \mathrm{nM}$ SCG. To investigate formation of 5'-OH omeprazole from omeprazole, the reactions were initiated by adding $200 \mu \mathrm{M}$ omeprazole and were terminated with $600 \mu \mathrm{l}$ of ice-cold dichloromethane after $10 \mathrm{~min}$ incubation at $37^{\circ} \mathrm{C}$ [27]. To investigate conversion of testosterone to $15 \beta-\mathrm{OH}$ testosterone, the reactions were initiated by the addition of $200 \mu \mathrm{M}$ testosterone and were stopped with $25 \mu \mathrm{l}$ of $1 \mathrm{~N} \mathrm{HCl}$ containing $2 \mathrm{M} \mathrm{NaCl}$ and $500 \mu \mathrm{l}$ of ice-cold ethyl acetate after $20 \mathrm{~min}$ incubation at $37^{\circ} \mathrm{C}$ [28]. After centrifuge samples at $3000 \mathrm{rpm}$ for $10 \mathrm{~min}$, organic layer was transferred to a new tube and evaporated under nitrogen gas. The products were analyzed by high performance liquid chromatography (HPLC) equipped with Gemini C18 column $(150 \times 4.6 \mathrm{~mm}, 5 \mu \mathrm{m}$; Phenomenex, USA). Mobile phase was acetonitrile/water (30:70, v/v) for omeprazole and methanol/water $(60: 40$, v/v) for testosterone. Flow rate was $1 \mathrm{ml} / \mathrm{min}$. The products of ome- prazole and testosterone were detected at $302 \mathrm{~nm}$ and $240 \mathrm{~nm}$, respectively.

\section{Bioinformatics analysis}

DNA and amino acid sequences of G6PDHs were found at the National Center for Biotechnology and Information [29] and UniProt Knowledgebase [30]. The UniProtKB entry names of G6PDHs used in this study are shown in Table S1. The amino acid sequences of G6PDHs were aligned by CLUSTALW [31]. Identities of amino acid sequences of G6PDHs were analyzed using Basic Local Alignment Search Tool [32]. The amino acid sequence of His-G6PDH was deduced from the DNA sequence of G6PDH-NX-pET-28 using the Translate Tool [33]. Molecular mass and extinction coefficient of HisG6PDH were predicted to be $60734.18 \mathrm{Da}$ and 64665 $\mathrm{M}^{-1} \mathrm{~cm}^{-1}$ at $280 \mathrm{~nm}$ by ProtParam [34]. All sequence graphics were made using BioEdit program [35].

\section{Statistical analysis}

All experiments were performed three times. The values are presented as means with standard errors (SEs) of three independent experiments.
A

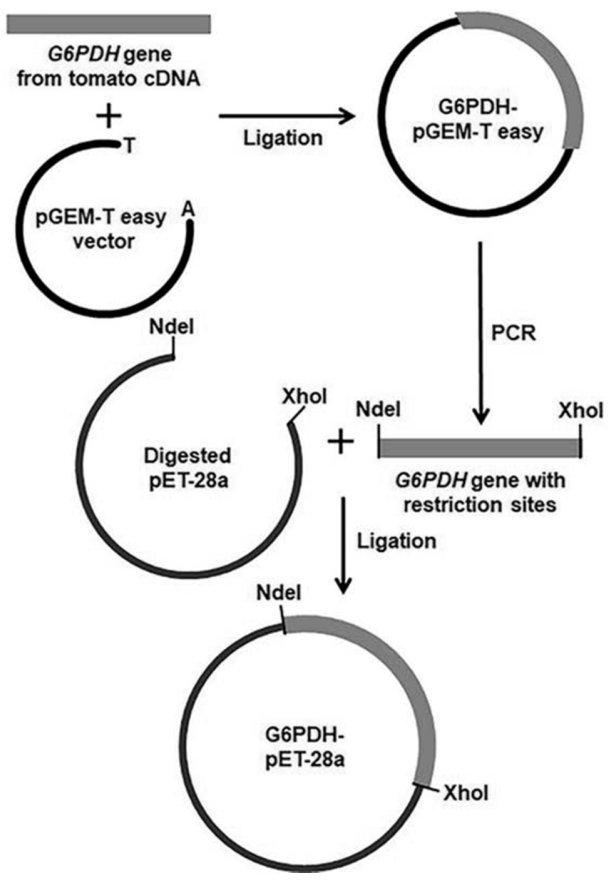

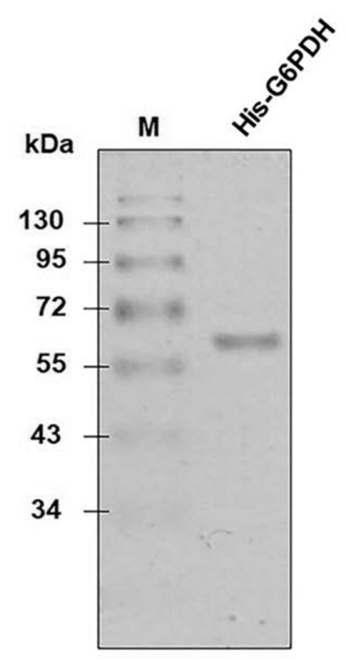

Fig. 1. Cloning of S. Iycopersicum G6PDH gene and heterologous expression in E. coli. (A) Strategy for cloning of tomato G6PDH gene into expression vector pET-28a. (B) Purified His-G6PDH $(1 \mu \mathrm{g})$ was loaded into $10 \%$ acrylamide gel with protein size markers that were indicated as M. After SDS-PAGE, the gel was stained with Coomassie Brilliant Blue R-250. 


\section{Results}

\section{Cloning of S. lycopersicum G6PDH gene}

The DNA sequence of cytosolic G6PDH from $S$. lycopersicum (Gene ID: 101249507) was found at NCBI. Based on this sequence, specific primers were designed for cloning. The $66 P D H$ gene was amplified by PCR using cDNA from $S$. lycopersicum as a template and cloned to expression vector pET-28a (Fig. 1A). DNA sequence of His-G6PDH is shown in Fig. S1.

\section{Heterologous expression and purification of His-G6PDH}

His-G6PDH has 531 amino acid residues including Nterminal 6xHis-tag (Fig. S2). Expression of His-G6PDH was induced by IPTG in $E$. coli and about $50 \%$ of expressed His-G6PDH existed as soluble form. HisG6PDH was purified by affinity chromatography (Fig. S3). The purified His-G6PDH was detected as a single protein band between 55 and $72 \mathrm{kDa}$ in SDS-PAGE (Fig. 1B).

\section{Comparison of activity among His-G6PDH, LMG, and SCG}

To evaluate catalytic activity of the purified enzyme, His-G6PDH activity was compared with those of LMG and SCG. Activity of $5 \mathrm{nM}$ His-G6PDH, LMG, and SCG was 1480,11300 , and $5300 \mu \mathrm{mol} / \mathrm{min} / \mu \mathrm{mol}$, respectively (Figs. 2A and B). In addition, we investigated whether His-G6PDH could generate comparable concentrations of NADPH produced by LMG and SCG. 21.1, 9.2, and $8.5 \mu \mathrm{M}$ NADPH were produced by $0.5 \mathrm{nM} \mathrm{LMG}, 0.5 \mathrm{nM}$ $\mathrm{SCG}$, and $2 \mathrm{nM}$ His-G6PDH for $5 \mathrm{~min}$, respectively. For 20 min reaction, 59, 25, and $24.2 \mu \mathrm{M}$ NADPH were generated by $0.5 \mathrm{nM} \mathrm{LMG}, 0.5 \mathrm{nM}$ SCG, and $2 \mathrm{nM}$ HisG6PDH, respectively (Fig. 2C). These results indicate that 4-10 fold of His-G6PDH than LMG or SCG is required to generate equal concentration of $\mathrm{NADPH}$.

\section{Kinetic characterization of His-G6PDH}

Kinetic parameters $\left(K_{\mathrm{m}}\right.$ and $\left.V_{\max }\right)$ of purified HisG6PDH were determined at one fixed concentration of two substrates. The His-G6PDH showed typical Michaelis-Menten kinetics for $\mathrm{G} 6 \mathrm{P}$ and $\mathrm{NADP}^{+}$substrates in addition to LMG and SCG (Fig. S4). Kinetic parameters of His-G6PDH, LMG, and SCG are shown in Table $1 . K_{\mathrm{m}}$ values were similar among all enzymes tested here, while $V_{\max }$ values were distinct among enzymes. His-
A

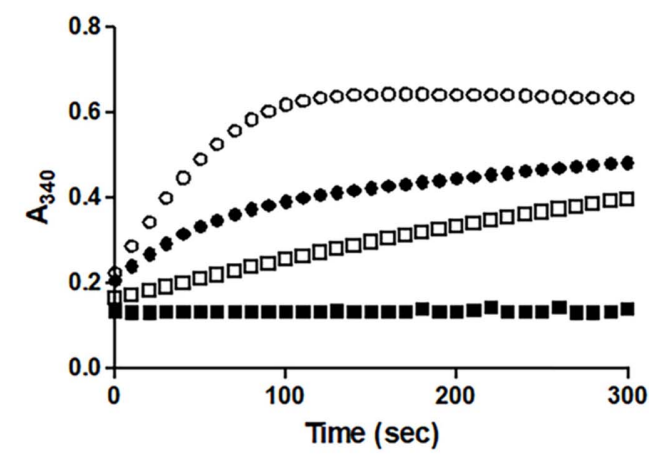

B

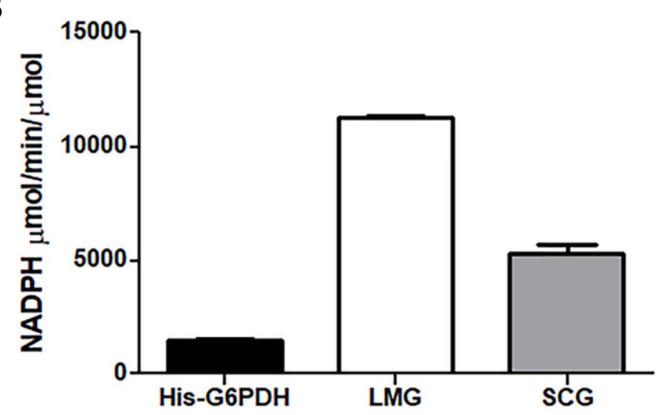

C

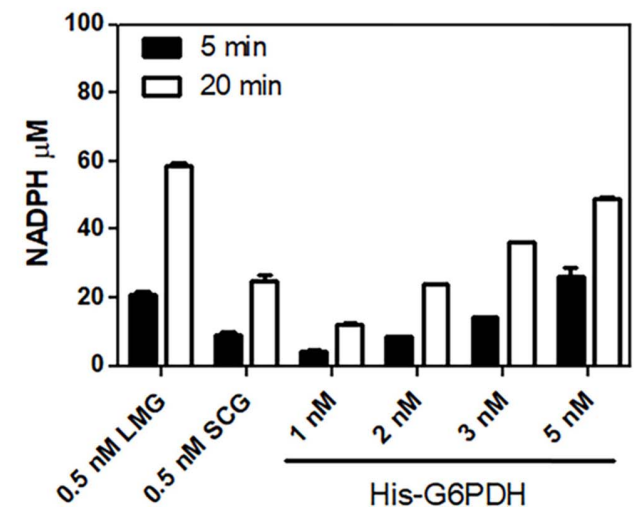

Fig. 2. Comparison of His-G6PDH activity with commercial G6PDH enzymes. (A) Generation of NADPH by His-G6PDH ( $\square$ ), LMG (O), or SCG (๑) was monitored at $340 \mathrm{~nm}$ at $37^{\circ} \mathrm{C}$ for $5 \mathrm{~min}$. Closed square ( $\boldsymbol{\square})$ indicates control without enzymes. (B) Activity $(\mu \mathrm{mol} / \mathrm{min} / \mu \mathrm{mol})$ of three enzymes was calculated by the molar attenuation coefficient of NADPH and initial velocity $\left(v_{0}\right)$ which was obtained from slop of Fig. 2A. (C) NADPH concentration $(\mu \mathrm{M})$ generated by $0.5 \mathrm{nM}$ LMG, $0.5 \mathrm{nM} \mathrm{SCG}$, or 1$5 \mathrm{nM}$ His-G6PDH for indicated times was calculated by the molar attenuation coefficient of NADPH and changes of absorbance over time $(\Delta \mathrm{A})$.

G6PDH showed much lower $V_{\max }$ value than those of LMG and SCG. The catalytic efficiency $\left(V_{\max } / K_{\mathrm{m}}\right)$ of HisG6PDH for G6P was $2.26 \mathrm{~min}^{-1} \mu \mathrm{M}^{-1}$, which was 6.9 -fold and 4.4-fold lower than LMG and SCG, respectively. The 
catalytic efficiency $\left(V_{\max } / K_{\mathrm{m}}\right)$ of His-G6PDH for NADP ${ }^{+}$ was $17.8 \mathrm{~min}^{-1} \mu \mathrm{M}^{-1}$, which was 6.4-fold and 2.3-fold lower than LMG and SCG, respectively.

To investigate the coenzyme preference of HisG6PDH, we performed G6PDH activity assay with $\mathrm{NAD}^{+}$instead of $\mathrm{NADP}^{+}$. His-G6PDH could not catalyze $\mathrm{NAD}^{+}$-linked reactions (Fig. S5). This result indicates that G6PDH from S. lycopersicum is a $\mathrm{NADP}^{+}$-specific enzyme.
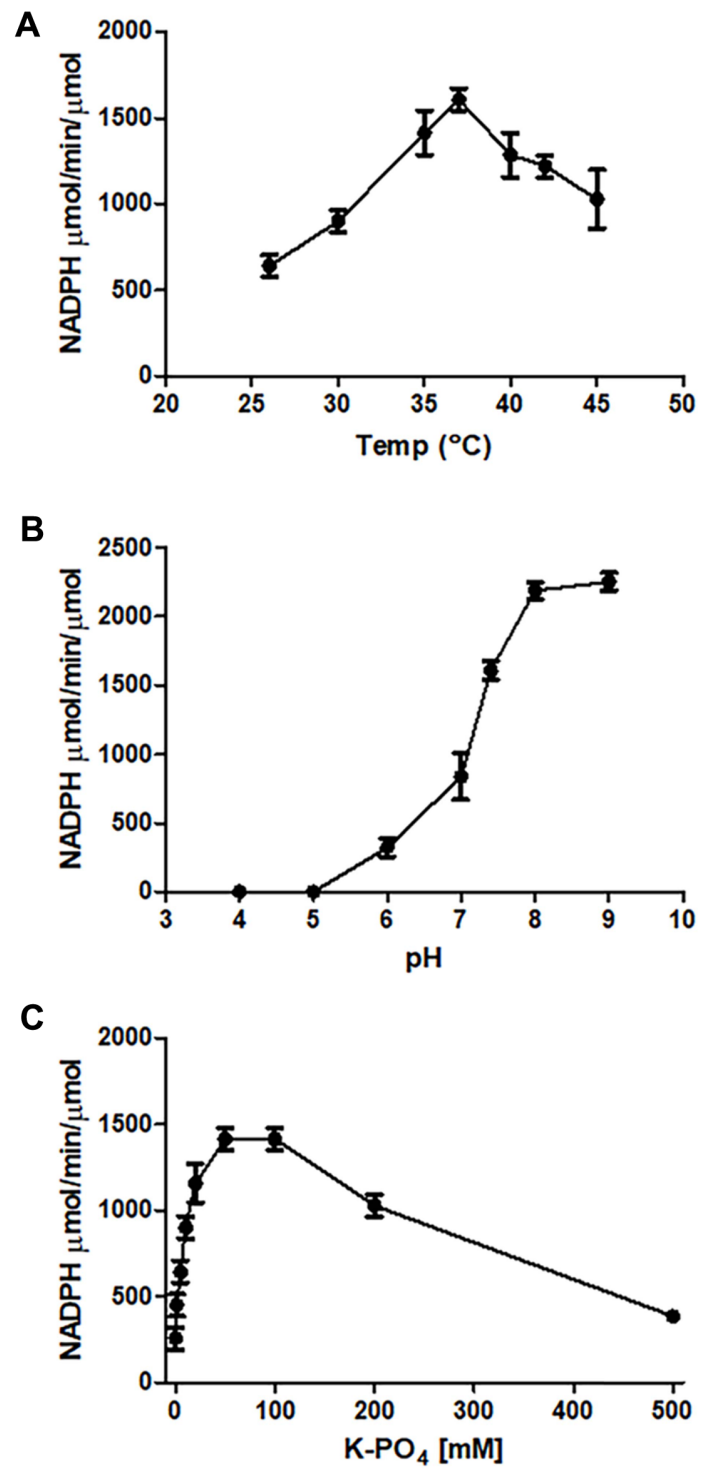

Fig. 3. Optimal conditions for His-G6PDH activity. Effects of temperature (A), $\mathrm{pH}(\mathrm{B})$, and buffer concentration (C) on HisG6PDH activity were analyzed as described in the Material and methods.

\section{Effect of temperature, $\mathrm{pH}$, and buffer concentration on His-G6PDH activity}

To define optimal conditions for His-G6PDH activity, G6PDH assay was performed at a different temperature, $\mathrm{pH}$, and buffer concentration. His-G6PDH was active in a wide temperature range of 26 to $45^{\circ} \mathrm{C}$. The optimal temperature was $37^{\circ} \mathrm{C}$ with $1610 \mu \mathrm{mol} / \mathrm{min} /$ $\mu$ mol (Fig. 3A). When the effect of $\mathrm{pH}$ on His-G6PDH activity was investigated at a range of $\mathrm{pH} 4$ to 9 , HisG6PDH was active between $\mathrm{pH} 6$ and 9. Although the maximal activity of His-G6PDH was shown at $\mathrm{pH} 9$ with $2250 \mu \mathrm{mol} / \mathrm{min} / \mu \mathrm{mol}$, it showed an apparent activity with $1610 \mu \mathrm{mol} / \mathrm{min} / \mu \mathrm{mol}$ at $\mathrm{pH} 7.4$ (Fig. 3B). In addition, the best concentration of potassium phosphate (pH 7.4) was at $50-100 \mathrm{mM}$ with $1414 \mu \mathrm{mol} / \mathrm{min} / \mu \mathrm{mol}$ (Fig. 3C). These results imply that His-G6PDH has potential to support $\mathrm{P} 450$ reactions in a general $\mathrm{P} 450$ assay condition of $100 \mathrm{mM}$ potassium phosphate buffer (pH 7.4) at $37^{\circ} \mathrm{C}$.

\section{Application of His-G6PDH to P450 activity assay}

To investigate whether His-G6PDH can be applied to NGS for P450 assay, we performed P450 activity assay using CYP102A1 mutant and its well-known substrates, omeprazole and testosterone [27, 28]. Because $2 \mathrm{nM}$ HisG6PDH generated similar concentration of NADPH with that generated by $0.5 \mathrm{nM}$ SCG shown in Fig. 2C, we used $2 \mathrm{nM}$ His-G6PDH, $0.5 \mathrm{nM} \mathrm{LMG}$, and $0.5 \mathrm{nM}$ SCG for providing NADPH to $\mathrm{P} 450$ reaction. Formation of 5'-OH omeprazole by three different NGS-supported $\mathrm{P} 450$ reactions was analyzed by HPLC. The 5'-OH omeprazole metabolite was eluted at 3.7 min (Fig. 4B). Formation rate of 5'-OH omeprazole by His-G6PDH-, LMG-, and SCG-supported P450 reaction was 30.0, 28.6, and $30.6 \mathrm{nmol} / \mathrm{min} / \mathrm{nmol}$, respectively (Fig. $4 \mathrm{~A}$ ). Three testosterone metabolites of CYP102A1 mutants have been reported as $15 \beta-\mathrm{OH}, 16 \beta-\mathrm{OH}$, and $2 \beta-\mathrm{OH}$ testosterone [28]. The $15 \beta-\mathrm{OH}$ testosterone was a major metabolite by CYP102A1 mutant and it was eluted at $3.9 \mathrm{~min}$ (Fig. $4 \mathrm{D})$. Formation rates of $15 \beta-\mathrm{OH}$ testosterone by HisG6PDH-, LMG-, and SCG-supported P450 reaction were 2.0, 1.9, and $2.2 \mathrm{nmol} / \mathrm{min} / \mathrm{nmol}$, respectively (Fig. 4C). These results suggest that His-G6PDH can be an alternative enzyme source for NGS. 

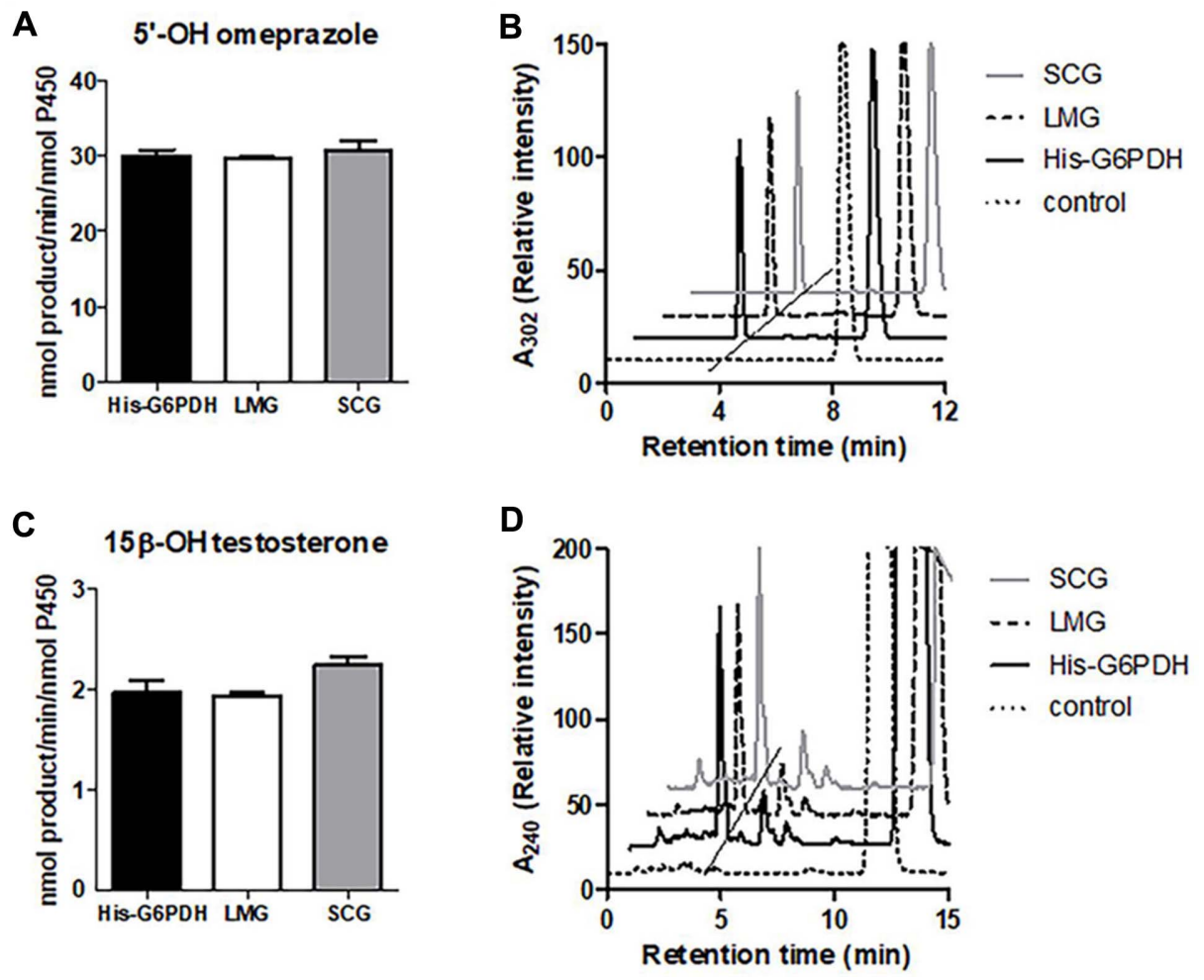

Fig. 4. Effect of distinct G6PDH on NADPH-dependent P450 activity. After incubating CYP102A1 mutant with NGS containing His-G6PDH, LMG, or SCG, P450 activities toward omeprazole (A, B) and testosterone (C, D) were analyzed by HPLC. (B) Retention times for omeprazole and $5^{\prime}-\mathrm{OH}$ omeprazole were $8.4 \mathrm{~min}$ and $3.7 \mathrm{~min}$, respectively. (D) Retention times for testosterone and $15 \beta$ $\mathrm{OH}$ testosterone were $11.7 \mathrm{~min}$ and $3.9 \mathrm{~min}$, respectively.

\section{Discussion}

According to safety testing of drug metabolites guidance for industry of Food and Drug Administration (FDA), identification and toxicity studies of drug metabolites are required to develop novel drugs [36]. Human P450s are involved in almost drug metabolism including steroids, xenobiotics, fatty acids, eicosanoids, and vitamins [37]. Thus, identification and production of drug metabolites by human $\mathrm{P} 450$ s are important in drug industry. However, some challenges exist for applications of human P450s in related biotechnological fields, because they have low activity, stability, and solubility [38]. To overcome these challenges, soluble bacterial P450s have applied to study drug metabolites. In particular, a set of CYP102A1 mutants generated by random mutagenesis made it is possible to produce marketed drug metabolites in vitro [7].

In addition, high-cost nicotinamide cofactor (NADPH) supply is essential for P450-catalyzed reaction. To overcome dependency on NADPH of $\mathrm{P} 450$ reaction, several different approaches have been reported such as the whole-cell system [39,40], enzyme-coupled cofactor regenerating [9, 10], peroxide shunt [41], and direct electron supply from electrodes [42]. Among them, G6PDHcoupled NADPH regenerating is widely used in $\mathrm{P} 450$ reactions. To our knowledge, only LMG and SCG can be purchased commercially and have used in NGS of P450 reactions.

In this study, we tried to develop G6PDH of $S$. lycopersicum as an alternative enzyme source of NGS. To understand S. lycopersicum G6PDH protein, the amino acid sequence of $S$. lycopersicum G6PDH was aligned with other G6PDHs belonging to the Solaneaceae family, which are from Solanum tuberosum (potato) and Capsicum annuum (bell pepper) (Fig. S6). We found four conserved sequences in S. lycopersicum G6PDH: Rossmanfold motif (residues 36-42 of the S. lycopersicum enzyme: 
Table 1. Kinetic parameters of NADPH formation by His-G6PDH, LMG, and SCG.

\begin{tabular}{ccccccc}
\hline Enzyme & $\begin{array}{c}K_{\mathrm{m}, \mathrm{GGP}} \\
(\mu \mathrm{M})\end{array}$ & $\begin{array}{c}K_{\mathrm{m}, \mathrm{NADP}+} \\
(\mu \mathrm{M})\end{array}$ & $\begin{array}{c}V_{\max , \mathrm{GGP}} \\
\left(\mathrm{min}^{-1}\right)\end{array}$ & $\begin{array}{c}V_{\max , \text { NADP }+} \\
\left(\mathrm{min}^{-1}\right)\end{array}$ & $\begin{array}{c}V_{\max , G 6 P} / K_{\mathrm{m}, G 6 P} \\
\left(\mathrm{~min}^{-1}, \mu \mathrm{M}^{-1}\right)\end{array}$ & $\begin{array}{c}V_{\text {max,NADP+}} / K_{\mathrm{m}, \mathrm{NADP}+} \\
\left(\mathrm{min}^{-1}, \mu \mathrm{M}^{-1}\right)\end{array}$ \\
\hline His-G6PDH & $654 \pm 89$ & $112 \pm 15$ & $1480 \pm 60$ & $1990 \pm 70$ & 2.26 & 17.8 \\
LMG & $640 \pm 37$ & $86.0 \pm 10.0$ & $9940 \pm 170$ & $9800 \pm 290$ & 15.5 & 114 \\
SCG & $527 \pm 29$ & $135 \pm 19$ & $5280 \pm 80$ & $5600 \pm 210$ & 10.0 & 41.5 \\
\hline
\end{tabular}

Assays were performed using $5 \mathrm{nM}$ enzymes. Kinetic parameters $\left(K_{\mathrm{m}}\right.$ and $\left.V_{\max }\right)$ were determined using nonlinear regression with MichaelisMenten equation of GraphPad PRISM software.

GASGDLA), conserved motif (residues 180-184 of $S$. lycopersicum enzyme: EKPFG), putative active region (residues 208-216 of $S$. lycopersicum enzyme: RIDHYLGKE), and $\mathrm{NADP}^{+}$-binding site (residues 385-393 of $S$. lycopersicum enzyme: NEFVIRLQP) [18, 21, 43] (Fig. S6). Amino acid sequence identity of $S$. lycopersicum G6PDH to S. tuberosum and C. annuum G6PDH was $99 \%$ and $96 \%$, respectively. This analysis suggests that amino acid sequences responsible for substrate binding and/or enzyme activity are well conserved in all organisms and G6PDH amino acid sequences of Solaneaceae family are highly conserved with more than $96 \%$ identity. When the amino acid sequence of $S$. lycopersicum G6PDH was compared to those of commercially available LMG and SCG, the identities were $31 \%$ and $52 \%$, respectively (Fig. S7). The identity between LMG and SCG was 35\%. Among four conserved regions of plant G6PDHs, the $\mathrm{NADP}^{+}$-binding site was not observed at bacterial LMG.

Kinetic properties of G6PDH from potato [17], LMG [44], and SCG [45] were investigated at $25^{\circ} \mathrm{C}$. It was reported that even $26^{\circ} \mathrm{C}$ inhibited growth and development of tomato [46]. However, the optimal temperature of His-G6PDH in this study was at $37^{\circ} \mathrm{C}$ (Fig. 3A). The kinetic parameters of His-G6PDH also were determined at $37^{\circ} \mathrm{C}$ (Table 1 and Fig. S4) and it showed unusual trend in temperature.

Plant G6PDHs have been reported that they were active in a broad range of $\mathrm{pH}$ 7-10. For example, optimal $\mathrm{pH}$ of G6PDH from potato, barely, and Arabidopsis exhibited at $\mathrm{pH}$ 7.5-9, $\mathrm{pH} 7-10$, and $\mathrm{pH}$ 8-8.5, respectively [15-17]. Similarly, His-G6PDH was active at $\mathrm{pH}$ 6-9 and the highest activity showed at pH 9 (Fig. 3B). In addition, the maximal activities of LMG and SCG were reported to be at $\mathrm{pH} 7.8$ and $\mathrm{pH} 8.5$, respectively $[47,48]$.

It is known that G6PDH has a different preference for coenzymes, $\mathrm{NADP}^{+}$and $\mathrm{NAD}^{+}$. G6PDHs from barley and Arabidopsis are specific for $\mathrm{NADP}^{+}$but not $\mathrm{NAD}^{+}$ $[15,16]$. SCG is a $\mathrm{NADP}^{+}$-preferring enzyme, while $\mathrm{LMG}$ catalyzes both $\mathrm{NAD}^{+}$- and $\mathrm{NADP}^{+}$-linked reactions [44, 45]. Here, His-G6PDH was found to be a $\mathrm{NADP}^{+}$-specific enzyme (Fig. S5). This result indicates that His-G6PDH could support $\mathrm{P} 450$ reactions by only generating NADPH.

Coexpression of G6PDH and CYP genes increased the efficiency of P450-mediated bioconversion in yeast system [49]. In plants, transient expression of CYP genes are useful for the production of valuable compounds [50, 51]. These reports suggest that heterologous expression of plant G6PDHs can be essential for P450-mediated bioconversion in plant system.

In conclusion, we first report the application of plant $\mathrm{G} 6 \mathrm{PDH}$ to $\mathrm{P} 450$-catalyzed reaction. We investigated the enzymatic properties of His-G6PDH and optimized NGS with His-G6PDH for P450 assay. Although specific activity of His-G6PDH was lower than those of commercial enzymes, His-G6PDH could sufficiently support NGS for P450-catalyzed reactions. Since His-G6PDH can be easily expressed in $E$. coli and purified using affinity chromatography, His-G6PDH could be a costeffective alternative that applies to NSG for P450-catalyzed bioconversion as well as other NADPH-needed reactions in laboratory research and related industries.

\section{Acknowledgments}

This study was supported by the grants from the National Research Foundation of Korea (NRF-2018M3A9F3079566), Republic of Korea and the Next-Generation BioGreen 21 program (SSAC, grant no: PJ013331012019), Rural Development Administration.

\section{Conflict of Interest}

The authors have no financial conflicts of interest to declare. 


\section{References}

1. Guengerich FP. 2001. Common and uncommon cytochrome P450 reactions related to metabolism and chemical toxicity. Chem. Res. Toxicol. 14: 611-650.

2. Guengerich FP, Munro AW. 2013. Unusual cytochrome P450 enzymes and reactions. J. Biol. Chem. 288: 17065-17073.

3. Guengerich FP. 2008. Cytochrome P450 and chemical toxicology. Chem. Res. Toxicol. 21: 70-83.

4. Tang W, Stearns RA. 2001. Heterotropic cooperativity of cytochrome P450 3A4 and potential drug-drug interactions. Curr. Drug Metab. 2: 185-198.

5. Munro AW, Daff S, Coggins JR, Lindsay JG, Chapman SK. 1996. Probing electron transfer in flavocytochrome P-450 BM3 and its component domains. Eur. J. Biochem. 239: 403-409.

6. Yun $\mathrm{CH}$, Kim KH, Kim DH, Jung HC, Pan JG. 2007. The bacterial P450 BM3: a prototype for a biocatalyst with human P450 activities. Trends Biotechnol. 25: 289-298.

7. Kang JY, Ryu SH, Park SH, Cha GS, Kim DH, Kim KH, et al. 2014. Chimeric cytochromes P450 engineered by domain swapping and random mutagenesis for producing human metabolites of drugs. Biotechnol. Bioeng. 111: 1313-1322.

8. Lussenburg BMA, Babel LC, Vermeulen NPE, Commandeur JNM. 2005. Evaluation of alkoxyresorufins as fluorescent substrates for cytochrome P450 BM3 and site-directed mutants. Anal. Biochem. 341: 148-155.

9. Xu Z, Jing K, Liu Y, Cen P. 2007. High-level expression of recombinant glucose dehydrogenase and its application in NADPH regeneration. J. Ind. Microbiol. Biotechnol. 34: 83-90.

10. Uppada V, Bhaduri S, Noronha SB. 2014. Cofactor regenerationan important aspect of biocatalysis. Curr. Sci. 106: 946-957.

11. Kruger NJ, von Schaewen A. 2003. The oxidative pentose phosphate pathway: structure and organisation. Curr. Opin. Plant Biol. 6: 236-246.

12. Schnarrenber C, Oeser A, Tolbert NE. 1973. Two isoenzymes each of glucose-6-phosphate dehydrogenase and 6-phosphogluconate dehydrogenase in spinach leaves. Arch. Biochem. Biophys. 154: 438-448.

13. von Schaewen A, Langenkamper G, Graeve K, Wenderoth I, Scheibe R. 1995. Molecular characterization of the plastidic glucose-6-phosphate dehydrogenase from potato in comparison to its cytosolic counterpart. Plant Physiol. 109: 1327-1335.

14. Corpas FJ, Barroso JB, Sandalio LM, Distefano S, Palma JM, Lupianez JA, et al. 1998. A dehydrogenase-mediated recycling system of NADPH in plant peroxisomes. Biochem J. 330(Pt 2): 777-784.

15 Wakao S, Benning C. 2005. Genome-wide analysis of glucose-6phosphate dehydrogenases in Arabidopsis. Plant J. 41: 243-256.

16. Esposito S, Carfagna S, Massaro G, Vona V, Di Martino Rigano V. 2001. Glucose-6-phosphate dehydrogenase in barley roots: kinetic properties and localisation of the isoforms. Planta 212: 627-634.

17. Graeve K, von Schaewen A, Scheibe R. 1994. Purification, characterization, and CDNA sequence of glucose-6-phosphate dehy- drogenase from potato (Solanum tuberosum L.). Plant J. 5: 353361.

18. Castiglia D, Cardi M, Landi S, Cafasso D, Esposito S. 2015. Expression and characterization of a cytosolic glucose 6 phosphate dehydrogenase isoform from barley (Hordeum vulgare) roots. Protein Expr. Purif. 112: 8-14.

19. Cardi M, Chibani K, Castiglia D, Cafasso D, Pizzo E, Rouhier N, et al. 2013. Overexpression, purification and enzymatic characterization of a recombinant plastidial glucose-6-phosphate dehydrogenase from barley (Hordeum vulgare cv. Nure) roots. Plant Physiol. Biochem. 73: 266-273.

20. Yang Y, Fu Z, Su Y, Zhang X, Li G, Guo J, et al. 2014. A cytosolic glucose-6-phosphate dehydrogenase gene, ScG6PDH, plays a positive role in response to various abiotic stresses in sugarcane. Sci. Rep. 4: 7090.

21. Cardi M, Castiglia D, Ferrara M, Guerriero G, Chiurazzi M, Esposito S. 2015. The effects of salt stress cause a diversion of basal metabolism in barley roots: possible different roles for glucose-6-phosphate dehydrogenase isoforms. Plant Physiol. Biochem. 86: 44-54.

22. Liu J, Wang X, Hu Y, Hu W, Bi Y. 2013. Glucose-6-phosphate dehydrogenase plays a pivotal role in tolerance to drought stress in soybean roots. Plant Cell Rep. 32: 415-429.

23. Wang H, Yang L, Li Y, Hou J, Huang J, Liang W. 2016. Involvement of ABA- and $\mathrm{H}_{2} \mathrm{O}_{2}$-dependent cytosolic glucose-6-phosphate dehydrogenase in maintaining redox homeostasis in soybean roots under drought stress. Plant Physiol. Biochem. 107: 126-136.

24. Landi S, Nurcato R, De Lillo A, Lentini M, Grillo S, Esposito S. 2016. Glucose-6-phosphate dehydrogenase plays a central role in the response of tomato (Solanum lycopersicum) plants to short and long-term drought. Plant Physiol. Biochem. 105: 79-89.

25. Kim DH, Kim KH, Kim DH, Liu KH, Jung HC, Pan JG, et al. 2008. Generation of human metabolites of 7-ethoxycoumarin by bacterial cytochrome P450 BM3. Drug Metab. Dispos. 36: 2166-2170.

26. Omura T, Sato R. 1964. The carbon monoxide-binding pigment of liver microsomes. Il. solubilization, purification, and properties. J. Biol. Chem. 239: 2379-2385.

27. Ryu SH, Park BY, Kim SY, Park SH, Jung HJ, Park M, et al. 2014. Regioselective hydroxylation of omeprazole enantiomers by bacterial CYP102A1 mutants. Drug Metab. Dispos. 42: 1493-1497.

28. Vottero E, Rea V, Lastdrager J, Honing M, Vermeulen NP, Commandeur JN. 2011. Role of residue 87 in substrate selectivity and regioselectivity of drug-metabolizing cytochrome P450 CYP102A1 M11. J. Biol. Inorg. Chem. 16: 899-912.

29. NCBI. Available from https://www.ncbi.nlm.nih.gov. Accessed May 8, 2019.

30. UniProtKB. Available from https://www.uniprot.org/. Accessed May 8, 2019.

31. Multiple Sequence Alignment by CLUSTALW. Available from https://www.genome.jp/tools-bin/clustalw. Accessed May 8, 2019.

32. Basic Local Alignment Search Tool. Available from https:// blast.ncbi.nlm.nih.gov/Blast.cgi. Accessed May 8, 2019.

33. Translate Tool. Available from https://web.expasy.org/translate/. Accessed May 8, 2019. 
34. ProtParam tool. Available from https://web.expasy.org/protparam/. Accessed May 8, 2019.

35. Hall TA. 1999. BioEdit: a user-friendly biological sequence alignment editor and analysis program for Windows 95/98/NT. http:// www.mbio.ncsu.edu/BioEdit/bioedit.html. Accessed May 8, 2019.

36. Schadt S, Bister B, Chowdhury SK, Funk C, Hop CECA, Humphreys WG, et al. 2018. A Decade in the MIST: Learnings from Investigations of Drug Metabolites in Drug Development under the "Metabolites in Safety Testing" Regulatory Guidance. Drug Metab. Dispos. 46: 865-878.

37. Furge LL, Guengerich FP. 2006. Cytochrome P450 enzymes in drug metabolism and chemical toxicology: An introduction. Biochem. Mol. Biol. Educ. 34: 66-74.

38. Urlacher VB, Eiben S. 2006. Cytochrome P450 monooxygenases: perspectives for synthetic application. Trends Biotechnol. 24: 324330.

39. Schewe H, Kaup BA, Schrader J. 2008. Improvement of P450 (BM3) whole-cell biocatalysis by integrating heterologous cofactor regeneration combining glucose facilitator and dehydrogenase in E. coli. Appl. Microbiol. Biotechnol. 78: 55-65.

40. Siriphongphaew A, Pisnupong P, Wongkongkatep J, Inprakhon $P$, Vangnai AS, Honda K, et al. 2012. Development of a whole-cell biocatalyst co-expressing P450 monooxygenase and glucose dehydrogenase for synthesis of epoxyhexane. Appl. Microbiol. Biotechnol. 95: 357-367.

41. Cirino PC, Arnold FH. 2003. A self-sufficient peroxide-driven hydroxylation biocatalyst. Angew. Chem. Int. Ed. Engl. 42: 32993301.

42. Fantuzzi A, Fairhead M, Gilardi G. 2004. Direct electrochemistry of immobilized human cytochrome P450 2E1. J. Am. Chem. Soc. 126: 5040-5041.

43. Bian M, Li S, Wei H, Huang S, Zhou F, Zhu Y, et al. 2018. Heteroex- pression and biochemical characterization of a glucose-6-phosphate dehydrogenase from oleaginous yeast Yarrowia lipolytica. Protein Expr. Purif. 148: 1-8.

44. Levy HR, Daouk GH. 1979. Simultaneous analysis of NAD- and NADP-linked activities of dual nucleotide-specific dehydrogenases. Application to Leuconostoc mesenteroides glucose-6-phosphate dehydrogenase. J. Biol. Chem. 254: 4843-4847.

45. Adediran SA, Gbadegesin MR. 1995. Kinetics of the reaction of baker's yeast glucose-6-phosphate dehydrogenase with 5, 5'dithiobis (2-nitrobenzoic acid). Arch. Biochem. Biophys. 322: 3942.

46. Cave CRJ, Cockshull KE, Adams SR. 2001. Effect of temperature on the growth and development of tomato fruits. Ann. Bot. 88: 869877.

47. Demoss RD, Gunsalus IC, Bard RC. 1953. A glucose-6-phosphate dehydrogenase in Leuconostoc mesenteroides. J. Bacteriol. 66: 10-16.

48. Glaser L, Brown DH. 1955. Purification and properties of d-glucose-6-phosphate dehydrogenase. J. Biol. Chem. 216: 67-79.

49. Jeon H, Durairaj P, Lee D, Ahsan MM, Yun H. 2016. Improved $\mathrm{NADPH}$ regeneration for fungal cytochrome $\mathrm{P} 450$ monooxygenase by co-expressing bacterial glucose dehydrogenase in restingcell biotransformation of recombinant yeast. J. Microbiol. Biotechnol. 26: 2076-2086.

50. Gnanasekaran T, Vavitsas K, Andersen-Ranberg J, Nielsen AZ, Olsen CE, Hamberger B, et al. 2015. Heterologous expression of the isopimaric acid pathway in Nicotiana benthamiana and the effect of $\mathrm{N}$-terminal modifications of the involved cytochrome P450 enzyme. J. Biol. Eng. 9: 24-24.

51. Sheludko YV, Gerasymenko IM, Warzecha H. 2018. Transient expression of human cytochrome P450s 2D6 and 3A4 in Nicotiana benthamiana provides a Possibility for Rapid Substrate Testing and Production of novel compounds. Biotechnol. J. 13: e1700696. 